\title{
Efektivitas Penggunaan Bahan Ajar Kalkulus Berbasis ICT Terintegrasi Masalah Kontekstual untuk Meningkatkan Aktivitas, Motivasi, dan Hasil Belajar Mahasiswa
}

\author{
Dewi Murni, Helma, Mirna \\ Jurusan Matematika, FMIPA Universitas Negeri Padang \\ dewimurni_mat@fmipa.unp.ac.id
}

\begin{abstract}
This research is part of the development research on Calculus teaching materials. The purpose of this study was to see the effectiveness of using Technology Information Comunication-based calculus teaching materials integrated contextual issues, especially to find out the activities and motivation of student learning while using the calculus teaching materials. Instruments for collecting data in research observation sheets and questionnaires. The data analysis technique used is descriptive statistical analysis. The results of the study are teaching materials Calculus can activate students in lectures and increase students' skills in utilizing information technology progress and can increase learning motivation, student perseverance and enthusiasm in Calculus lectures.
\end{abstract}

Keywords : Activity, Learning motivation, Calculus, Teaching materials

his is an open access article distributed under the Creative Com reproduction in any medium, provided the original work is properly cited. $\odot 2018$ by author and Universitas Negeri Padang.

\section{PENDAHULUAN}

Kalkulus merupakan mata kuliah wajib pa da semua mahasiswa Tingkat Tahun Pertama di FMIPA UNP (Jurusan Matematika, Fisika, Ki mia dan Biologi), karena mata kuliah ini membe ri dasar pengetahuan untuk mata kuliah berikut nya. Materinya meliputi Fungsi, turunan dan In tegral (Purcell dkk,2011). Oleh sebab itu diperlu kan penguasaan sangat baik oleh mahasiswa, na mun kenyataannya sebagian besar mahasiswa ni lainya masih belum memuaskan dan terlihat be lum aktif dan termotivasi dalam belajar. Hal ini dapat dilihat dari aktivitas mahasiswa di kelas yang cendrung pasif, dan tidak mau bertanya. Kemudian pekerjaan rumah dibuat asal asalan seperti : hanya menulis soal saja, jawaban benar tetapi sewaktu diminta menjelaskan tidak bisa. Berdasarkan permasalahan tersebut maka perlu dicarikan solusi yang dapat meningkatkan moti vasi dan aktivitas belajar mahasiswa. Salah satu satu solusi yang diperkirakan dapat mengatasi masalah tersebut adalah dengan memanfaatkan Technology Information \& Comunication (ICT) dan mengaitkan materi-materi dengan masalah kontesktual.

Seiring dengan perkembangan teknologi, informasi dan komunikasi saat ini pemanfaatan teknologi yang optimal, khususnya dalam media pembelajaran akan membuat mahasiswa lebih tertarik, lebih mudah untuk memahami dan me ningkatkan motivasi belajar mahasiswa. Dengan bantuan komputer beberapa grafik dapat divi sualisasikan dengan baik sehingga pembelajaran menjadi lebih menarik dan mudah dipahami. Begitu juga beberapa perhitungan kalkulus dapat juga diuji dengan software komputer sehingga mahasiswa dapat meningkatkan proses berpikir mereka. Setiawan \& Darminto (2016), telah me neliti dengan judul "Meningkatkan Kemampuan Berpikir Matematis Tingkat Tinggi (KBMTT) mahasiswa calon guru matematika melalui pem belajaran matematika berbasis komputer dengan menggunakan program aplikasi mutimedia inter aktif'. Selanjutnya Kartika (2014) mengemuka kan "pembelajaran matematika berbantuan soft ware matlab dapat meningkatkan kemampuan komunikasi matematis dan minat belajar siswa SMA”. Teguh Saryanto (2005) pada pengguna an Media pembelajaran berbantu komputer menyimpulkan bahwa "(1) Pembelajaran dengan menggunakan media komputer dapat memudah kan guru dalam penyampaian pelajaran, (2) Me dia pembelajaran matematika berbantukan kom puter sebagai alat untuk meningkatkan motivasi siswa terhadap pelajaran matematika serta dapat meningkatkan efektivitas pendidikan dengan pe nyelesaian persoalan yang cepat dan akurat". Se lanjutnya materi yang dikaitkan dengan masalah kontekstual diperkirakan juga dapat membuat materi lebih menarik untuk dipelajari mahasis wa. Dengan pratikum di labor mahasiswa akan bisa berlatih lebih baik. Penggunaan ICT yang tepat diharapkan dapat meningkatkan pemaham an konsep Kalkulus mahasiswa, ini seperti yang dikemukakan Paltimer (1991) pada media Metro fik, "Membandingkan pembelajaran kalkulus 
yang menggunakan computer dengan pembela jaran konvensional menunjukkan bahwa hasil pembelajaran berbasis komputer lebih baik dari pada pembelajaran konvensional. Tetapi, tidak setiap pembelajaran harus diselenggarakan mela lui pembelajaran berbasis TIK. Beberapa kegiat an pembelajaran masih harus diselenggarakan dengan pembelajaran konvensional". Agar pem belajaran berbasis $I C T$ dan terintegrasi masalah kontektual dapat berjalan efektif maka diperlu kan Bahan Ajar sebagai panduan dalam pem belajaran.

Fungsi motivasi menurut Oemar Hamalik dalam Martinis Yamin (2006) meliputi sebagai berikut: (1) Mendorong timbulnya kelakuan atau suatu perbuatan, seperti perbuatan belajar, (2) Motivasi berfungsi sebagai pengarah. Artinya mengarah perbuatan kepencapaian tujuan yang diinginkan, (3) Motivasi berfungsi sebagai peng gerak. Tinggi rendahnya motivasi akan menentu kan cepat atau lambatnya suatu pekerjaan. Pe ningkatan motivasi mahasiswa dapat dilihat dari berbagai aspek seperti yang telah dikemukakan Schunk and Zimmerman (2009): "Among sour ce of motivation the are: interests, self-efficacy, volition, task values, confidence in learning, out come expectancy and future time per spective". Pendapat di atas menjelaskan bahwa motivasi da pat dilihat dari: minat, kemandirian, kemauan, ni lai ulangan, kepercayaan diri dalam belajar, ori entasi pada hasil, dan pandangan terhadap masa depan.

Seorang mahasiswa yang sudah termoti vasi untuk belajar maka aktivitas belajarnya cen derung meningkat (Helma, 2019). Banyak aktivi tas yang bisa dikembangkan oleh mahasiswa, seperti yang dikemukakan Sardiman (2006) yai tu: (1) Visual activities, diantaranya meliputi membaca, memperhatikan gambar demonstrasi, percobaan; (2) Oral activities, seperti menyata kan, merumuskan, bertanya, memberi saran, dan mengeluarkan pendapat; (3) Listening activities, seperti misalnya mendengarkan percakapan, dis kusi dan pidato; (4) Writing activities, misalnya menulis cerita, karangan, laporan dan menyalin; (5) Motor activities, misalnya melakukan perco baan, membuat konstruksi, model mereparasi, bermain, berkebun, beternak; (6) Mental activi ties, misalnya menanggapi, mengingat, meme cahkan soal, dan menganalisis; dan (7) Emo tional activities, misalnya, menaruh minat, mera sa bosan, gembira, bersemangat, bergairah, bera ni, tenang, gugup. Jadi dalam pembelajaran ber basis ICT yang dipandu bahan Ajar Kalkulus yang sudah dikembangkan diharapkan mahasis wa lebih termotivasi belajar, sehingga aktivitas dan hasil belajar mereka meningkat. Adapun pe laksanaan pembelajaran ini terdiri atas dua tahap yaitu latihan dan praktek, seperti yang dikemu kakan Simon dalam Wena (2009) terdapat tiga model penyampaian materi pelajaran berbasis komputer: a) Latihan dan Praktek; b) Tutorial. c) Simulasi. Dengan demikian, tujuan penelitian ini adalah untuk mengetahui efektivitas penggunaan ba han ajar Kalkulus berbasis ICT yaitu melihat motivasi, aktivitas dan hasil belajar mahasiswa.

\section{METODE PENELITIAN}

Jenis penelitian ini adalah penelitian kuali tatif. Menurut Moleong (2005), "penelitian kuali tatif adalah penelitian yang bermaksud untuk memahami fenomena tentang apa yang dialami oleh subjek penelitian misalnya perilaku, persep si, motivasi, tindakan, dll secara holistic, dan dengan cara deskripsi dalam bentuk kata-kata dan bahasa, pada suatu konteks khusus yang alamiah dan dengan memanfaatkan berbagai ma cam metode alamiah".

Subjek pada penelitian adalah mahasiswa jurusan matematika (30 orang) dan mahasiswa jurusan kimia (32 orang) tahun akademik 2018. Instrumen penelitian adalah lembar observasi, angket, dan tes hasil belajar. Teknik analisis data yang digunakan dalam penelitian ini yaitu ana lisis statistik deskriptif dan metoda grafik. Anali sis deksriptif digunakan untuk mengetahui infor masi lebih rinci dari: aktivitas, motivasi dan des kripsi kemampuan pemecahan masalah mahasis wa. Metoda grafik digunakan untuk memberikan kesan visual tentang efektivitas penggunaan ba han ajar Kalkulus Berbasis ICT Terintegrasi Ma salah kontekstual dalam pem belajaran.

\section{HASIL DAN PEMBAHASAN}

Hasil penelitian terdiri atas data aktivitas mahasiswa selama pembelajaran dilaksanakan, data tanggapan mahasiswa terhadap bahan ajar yang digunakan, data motivasi belajar mahasis wa, dan data kemampuan pemecahan masalah mahasiswa.

\section{Aktivitas Mahasiswa Saat Perkuliahan}

Aktivitas mahasiswa yang diamati selama perkuliahan kalkulus berlangsung terdiri dari ti ga tahap yaitu : a) tahap think (belajar mandiri) terdiri: memperhatikan penyajian materi oleh do sen, melakukan kegiatan sesuai petunjuk pada 
bahan ajar, menjawab pertanyaan pada bahan ajar dengan benar, memberikan komentar, b) tahap Pair (belajar kelompok) terdiri berdiskusi dengan pasangan kelompoknya tehadap hasil yang telah dikerjakan pada saat Think, meman faatkan bahan ajar Kalkulus, menjelaskan kepa da teman, c) tahap Share (diskusi kelas) terdiri: aktivitas bertanya, menjawab pertanyaan, menge mukakan pendapat. Data aktivitas diperoleh dari mahasiswa jurusan Matematika dan mahasiswa jurusan Kimia yang mengambil mata kuliah Kal kulus pada semester Juli-Desmber 2018 yang terpilih sebagai subjek penelitian.

\section{Aktivitas Mahasiswa Pada Saat Bekerja Sendiri (Think)}

Data aktivitas mahasiswa pada saat think diambil melalui obsevasi pada mahasiswa juru san Matematika dan jurusan Kimia. Secara gra fik, data tersebut dapat dilihat pada Gambar 1 dan Gambar2.

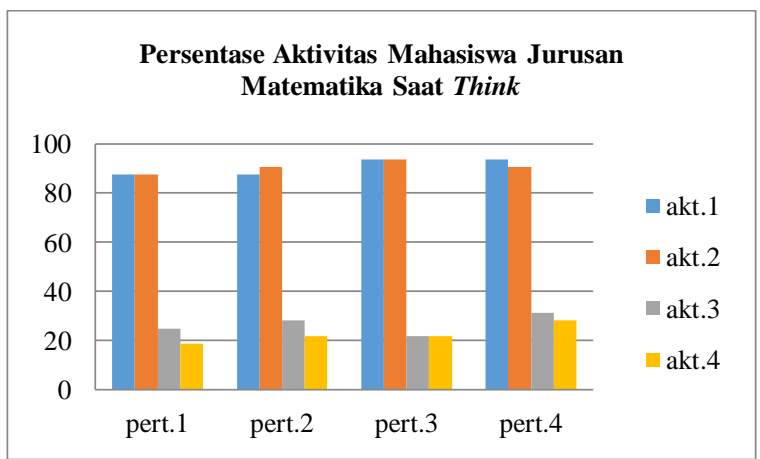

Gambar 1. Grafik Aktivitas Mahasiswa Jurusan Matematika Pada Saat Think

Berdasarkan Gambar 1 dapat diketahui sa at Think, secara umum pada semua aktivitas ter dapat kenaikan persentase mahasiswa yang aktif melakukan kegiatan terutama aktivitas meman faatkan bahan ajar meningkat dari 73,3\% menja di 93,3\%. Aktivitas-aktivitas yang hampir semua mahasiswa matematika (yaitu sekitar 90\%) me lakukannya yaitu aktivitas memperhatikan penje lasan dosen dan mencatat semua hasil peker jaannya. Hal ini menunjukkan selama penelitian berlangsung hampir semua mahasiswa serius me lakukan kegiatan perkuliahan sesuai petunjuk ba han ajar. Sedangkan aktivitas menjawab perta nyaan baik dari dosen maupun dari temannya dan aktivitas memberi komentar atas tampilan temannya memang belum begitu banyak terjadi tetapi sudah tejadi peningkatan pada setiap per temuan. Begitu pula untuk aktivitas siswa menja wab pertanyaan/ memberi komentar atas perta nyaan guru tejadi peningkatan pada setiap per temuan. Hal ini terlihat bahwa mahasiswa mera sa pembelajaran menggunakan media ICT yang dipandu bahan ajar berkaitan, ini membuat mere ka lebih perhatian dan ingin lebih tertarik untuk melihat hasil yang dikeluarkan oleh software setelah perintah diinputkan. Pada saat menjawab pertanyaan beberapa mahasiswa kurang mengin dahkan pertanyaan karena kebanyakan mereka masih sibuk dengan kegiatan mereka dengan komputer.

Selanjutnya, dari Gambar 2 dapat dilihat aktivitas mahasiswa jurusan kimia selama pem belajaran menggunakan Bahan ajar Kalkulus ber basis ICT berlangsung dengan baik dan terjadi peningkatan.

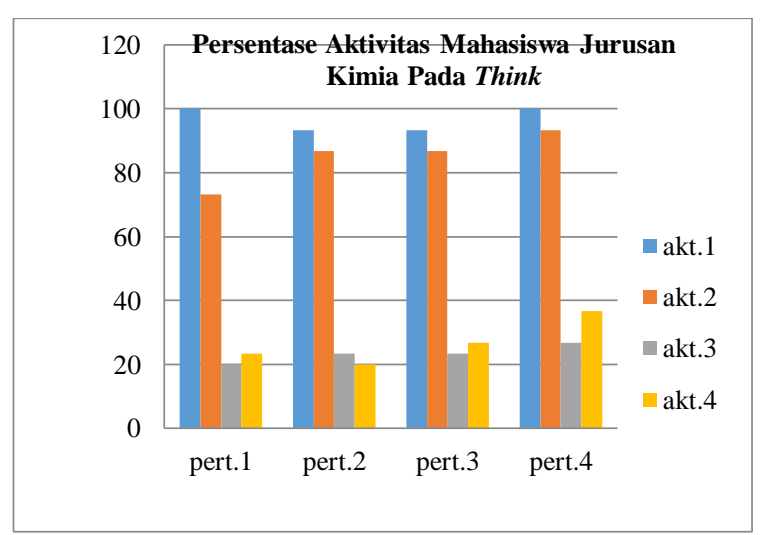

Gambar 2. Grafik Aktivitas Mahasiswa Kimia Pada Saat Think

Aktivitas yang juga paling banyak dilakukan ma hasiswa adalah : aktivitas mencatat semua hasil pekerjaan yang telah dilakukan menggunakan software Maple (100\%), aktivitas memperhati kan penjelasan dosen (meningkat dari $93 \%$ men jadi $100 \%$ ) dan aktivitas melakukan kegiatan se suai petunjuk bahan ajar berbasis ICT dengan baik (meningkat dari 73\% sampai 93\%). Akti vitas-aktivitas ini banyak dilakukan mahasiswa karena bekerja dengan software menarik bagi mereka karena dapat melihat hasil dari apa yang mereka cari secara cepat dan benar. Aktivitas lain yaitu menjawab pertanyaan dosen masih se dikit karena masing-masing masih sibuk dengan kegiatan mandiri mereka dan beberapa yang le bih cepat menyelesaikan lebih cepat dapat menja wab. Peningkatan jumlah mahasiswa pada akti vitas ini tidak begitu signifikan dari 6 orang (20\%) menjadi 8 orang $(26,7 \%)$. Sedangkan akti vitas memberi komentar meningkat dari $23,3 \%$ (7 orang) menjadi 36,7\% (11 orang).

Aktivitas Mahasiswa Pada Saat Diskusi Kelompok (Pair) 
Aktivitas mahasiswa pada saat diskusi ke lompok dilakukan setelah masing-masing maha siswa mencoba menyelesaikan tugas-tugas yang ada pada bahan ajar. Data aktivitas mahasiswa jurusan Matematika dan jurusan Kimia pada saat diskusi kelompok, secara gafik dapat dilihat pa da Gambar 3 dan Gambar 4. Dari Gambar 3 da pat dilihat pada saat Pair (diskusi berpasangan), di awal pertemuan semua mahasiswa (100\%) berdiskusi dengan teman disampingnya untuk mendiskusikan permasalahan yang mereka sele saikan.

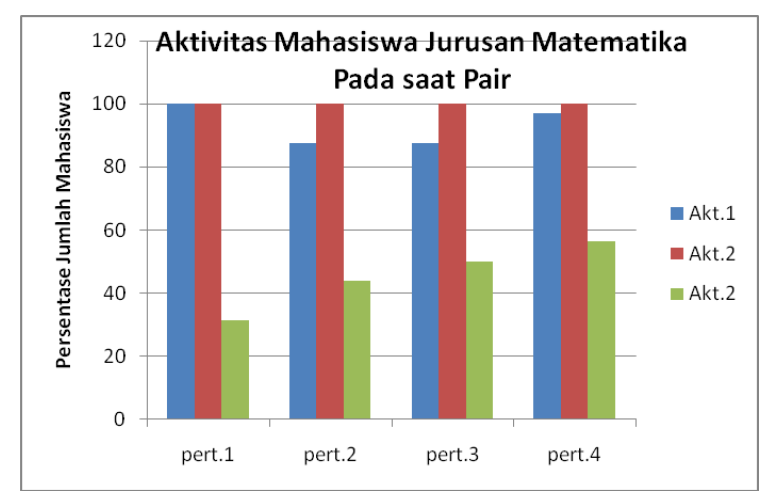

Gambar 3. Grafik Aktivitas Mahasiswa Matematika Pada Saat Diskusi Kelompok (Pair)

Namun di akhir pertemuan ada beberapa maha siswa (sekitar 2 atau 3 orang) yang sibuk sendiri bekerja dengan komputer tanpa berdiskusi de ngan teman disampingnya.

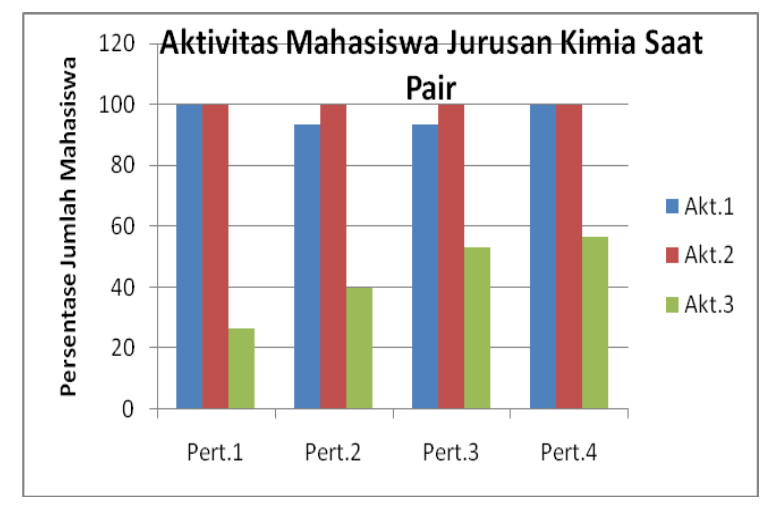

Gambar 4. Grafik Aktivitas Mahasiswa Jurusan

Kimia Saat Diskusi Kelompok (Pair)

Sedangkan aktivitas menggunakan bahan ajar berbasis ICT sebagai bahan perkuliahan dilaku kan oleh semua mahasiswa. Kemudian aktivitas menjelaskan kepada teman dengan baik mening kat cukup tajam dimana di awal perkuliahan ha nya 10 orang $(31,3 \%)$ yang bisa menjelaskan de ngan baik namun di akhir pertemuan terlihat su dah 18 orang (56,3\%). Hal ini disebabkan kare na sudah banyak mahasiswa yang mulai teram pil dalam menggunakan software dalam menye lesaikan soal-soal kalkulus.

Aktivitas yang dilakukan oleh mahasiswa jurusan Kimia yang paling banyak adalah : akti vitas berdiskusi dengan teman secara berpa sangan (berdua) dengan teman diampingnya, $100 \%$ diawal pertemuan dan $100 \%$ juga di akhir pertemuan artinya mahasiswa sudah suka berba gi dan berdiskusi dengan temannya tentang hasil yang diperoleh menyelesaikan soal-soal dengan menggunakan software dengan dipandu oleh ba han ajar berbasis ICT. Sedangkan tentang peng gunaan bahan ajar selama perkuliahan berlang sung semua mahasiswa memanfaatkannya. Akti vitas yang lain seperti aktivitas menjelaskan ke pada teman secara baik dan benar terjadi pening katan cukup tinggi karena semakin lama sema kin banyak mahasiswa mahir dan terampil meng gunakan software Maple sehingga semakin ba nyak yang bisa menjelaskan kepada temannya secara baik. Aktivitas menjelaskan meningkat da ri $26,7 \%$ (8 orang ) meningkat menjadi $56,7 \%$ (17 orang) di akhir pertemuan.

\section{Aktivitas Mahasiswa Pada Saat Diskusi Kelas (Share)}

Aktivitas diskusi kelas dilaksanakan di ba gian akhir pembelajaran dimana setelah maha siswa selesai menjawab pertanyaan yang ada da lam bahan ajar berbasis ICT. Beberapa maha siswa perwakilan kelompok menampilkan hasil pekerjaannya di depan kelas dan mahasiswa lain diminta menanggapi atau mengomentari. Data aktivitas mahasiswa jurusan Matematika dan Kimia pada saat share secara grafik dapat dilihat pada Gambar 5 dan Gambar 6.

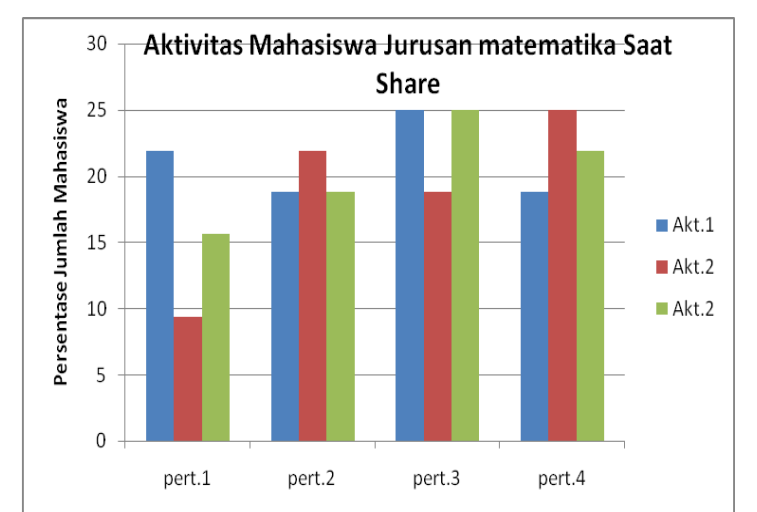

Gambar 5. Grafik Aktivitas Mahasiswa Jurusan Matematika Pada Saat Diskusi Kelompok (Share)

Dari Gambar 5 dan Gambar 6 dapat dilihat pada saat diskusi kelas, aktivitas yang dilakukan ma hasiswa jurusan Matematika pada tahap ini yaitu 
aktivitas bertanya, menjawab pertanyaan dan me ngemukakan pendapat. Aktivitas bertanya yang dilakukan tidak begitu banyak (sekitar 20\%) dan berfluktuatif, begitu pula halnya siswa yang men jawab pertanyaan/memberikan komentar, namun tetap terjadi peningkatan.

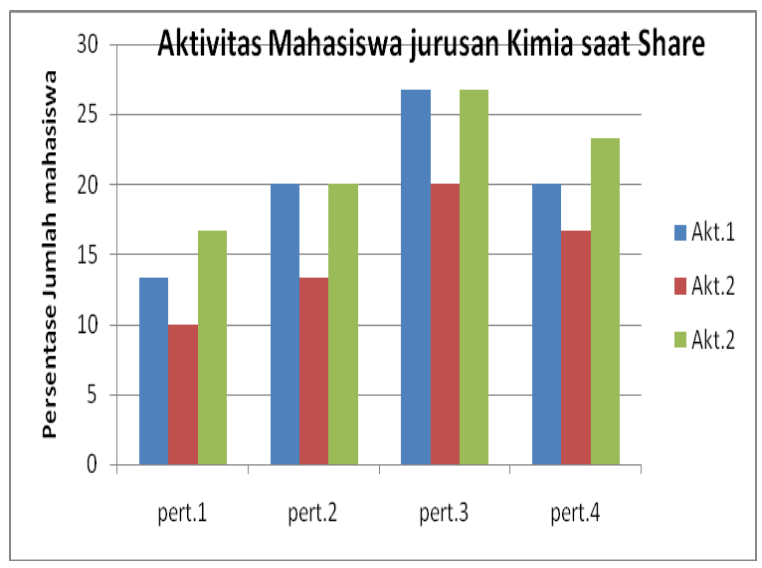

Gambar 6. Grafik Aktivitas Mahasiswa Jurusan kimia Pada Saat Diskusi Kelompok (Share)

Sedangkan aktivitas yang dilakukan mahasiswa jurusan kimia lebih sedikit lagi yang bertanya, hal ini disebabkan mereka lebih cendrung bisa menggunakan software dengan baik sehingga hasil yang mereka cukup baik dan benar sehing ga mereka tidak bertanya. Aktivitas menjawab pertanyaan dan mengemukakan pendapat juga tidak begitu banyak dilakukan tetapi kecende rungan ada juga peningkatan.

\section{Tanggapan Mahasiswa Terhadap Penggunaan Bahan Ajar}

Data tanggapan mahasiswa terhadap peng gunaan bahan ajar berbasis ICT dalam perku liahan diperoleh melalui angket yang diberikan kepada masiswa setelah perkuliahan menggu nakan bahan ajar berbasis ICT berakhir. Data ter sebut diperoleh dari mahasiswa jurusan Matema tika dan mahasiswa jurusan Kimia yang mengi kuti perkuliahan Kalkulus. Dari data tersebut di ketahui bahwa rata-rata mahasiswa mengatakan sangat setuju (SS) terhadap penggunaan bahan ajar berbasis ICT adalah sebanyak 38,5\% juru san matematika dan sebanyak $23,2 \%$ jurusan $\mathrm{Ki}$ mia. Sedangkan yang mengatakan setuju (S) ter hadap penggunaan bahan ajar berbasis ICT ada lah sebanyak $54,1 \%$ mahasiswa jurusan matema tika dan sebanyak $66,1 \%$ mahasiswa jurusan kimia. Adapun yang berpendapat tidak setuju (TS) terhadap penggunaan bahan ajar berbasis ICT adalah sebanyak 7,7\% dari mahasiswa juru san Matematika dan sebanyak 10,6\% dari juru san Kimia. Untuk yang berpendapat sangat tidak setuju (STS) tidak ada satupun dari kedua juru san baik jurusan matematika maupun jurusan Kimia. Dari jumlah tersebut dapat disimpulkan bahwa bahan ajar Kalkulus berbasis ICT sudah dapat dipakai karena mahasiswa yang sangat se tuju dan setuju sudah mencapai rata-rata $92 \%$ dari jurusan Matematika dan $89 \%$ dari jurusan Kimia.

\section{Motivasi Belajar Mahasiswa Selama Pembelajaran Menggunakan Bahan Ajar Berbasis ICT.}

Untuk mengetahui motivasi mahasiswa da lam perkuliahan ketika menggunakan bahan ajar Kalkulus yang dikembangkan maka telah dibe rikan angket kepada mahasiswa jurusan Matema tika dan mahasiswa jurusan Kimia yang terdiri dari 5 indikator: 1) Ketekunan Dalam Perkuliah an, 2) Sikap terhadap kesulitan yang dihadapi saat belajar Kalkulus, 3) Usaha untuk mengatasi kesulitan belajar Kalkulus, 4) Semangat dalam mengikuti perkuliahan semangat dalam mengi kuti perkuliahan, 5) Kebiasaan dalam mengikuti perkuliahan. Berikut adalah hasil yang diperoleh dari angket motivasi belajar.

\section{a) Indikator ketekunan dalam perkuliahan.}

Berdasarkan tiga aspek yang ditanya ke pada mahasiswa pada indikator "Ketekunan Da lam Perkuliahan" yaitu ketekunan mengikuti per kuliahan, semangat dalam menghadiri perkuliah an dan berdiskusi dengan teman dalam menye lesaikan soal atau permasalahan Kalkulus, maka diketahui bahwa mahasiswa jurusan matematika sekitar 70\% mahasiswa menjawab selalu (SL) dan sekitar 25\% menjawab sering (SR). Se dangkan mahasiswa jurusan Kimia sekitar 60\% menjawab selalu (SL) dan sekitar 30\% menja wab sering (SR). Hal ini berarti dalam menggu nakan bahan ajar berbasis ICT mahasiswa jurusn Matematika dan mahasiswa jurusan Kimia terma suk tekun dalam melaksanakan perkuliahan.

\section{b) Indikator sikap terhadap kesulitan yang dihadapi saat belajar Kalkulus.}

Berdasarkan dua aspek yang ditanya kepa da mahasiswa pada indikator "Sikap terhadap kesulitan yang dihadapi dalam pembelajaran" yaitu bersemangat mengerjakan kegiatan prak tikum pada bahan ajar Kalkulus berbasis ICT dan bersemanagat berdiskusi dengan teman un tuk menyelesaikan persoalan dalam bahan ajar, maka diketahui bahwa mahasiswa jurusan mate matika sekitar $62 \%$ mahasiswa menjawab selalu 
(SL) dan sekitar 37\% menjawab sering (SR). Sedangkan mahasiswa jurusan Kimia sekitar 59\% menjawab selalu (SL) dan sekitar 35\% men jawab sering (SR). Hal ini berarti dalam meng gunakan bahan ajar berbasis ICT mahasiswa ju rusan Matematika dan mahasiswa jurusan Kimia termasuk bersemangat dalam menyelesaikan so al-soal termasuk yang sulit.

\section{c) Indikator usaha untuk mengatasi kesulitan belajar Kalkulus}

Berdasarkan tiga aspek yang ditanya kepa da mahasiswa pada indikator "usaha untuk me ngatasi kesulitan belajar" yaitu berusaha menca ri penyelesaian soal-soal yang sulit, berusaha ber tanya sama teman untuk menyelesaikan soal yang sulit dan merasa tertantang untuk menyele saikan soal yang suli, maka diketahui bahwa ma hasiswa jurusan matematika sekitar $62 \%$ maha siswa menjawab selalu (SL) dan sekitar 37\% menjawab sering (SR). Sedangkan mahasiswa ju rusan Kimia sekitar 59\% menjawab selalu (SL) dan sekitar 35\% menjawab sering (SR). Hal ini berarti dalam menggunakan bahan ajar berbasis ICT mahasiswa jurusn Matematika dan mahasis wa jurusan Kimia termasuk bersemangat dalam menyelesaikan soal-soal termasuk yang sulit.

\section{d) Indikator semangat dalam mengikuti perkuliahan}

Data tentang semangat dalam mengikuti perkuliahan dapat dilihat pada Gambar 13 dan Gambar 14. Dari empat aspek yang ditanya kepa da mahasiswa pada indikator "Semangat dalam mengikuti PBM selama perkuliahan" yaitu tetap optimis dan semangat ketika mengalami kesulit an, merasa pembelajaran dengan software Maple menarik, merasa senang mengerjakan latihan de ngan software MAPLE, dan bersemangat mengi kuti kegiatan pratikum maka diketahui bahwa mahasiswa jurusan matematika sekitar 64\% mahasiswa menjawab selalu (SL) dan sekitar 33\% menjawab sering (SR). Sedangkan mahasis wa jurusan Kimia sekitar 54\% menjawab selalu (SL) dan sekitar $42 \%$ menjawab sering (SR). Hal ini berarti dalam menggunakan bahan ajar berbasis ICT mahasiswa jurusn Matematika dan mahasiswa jurusan Kimia termasuk bersemangat dalam mengikuti perkuliahan.

\section{e) Indikator kebiasaan dalam mengikuti perkuliahan}

Berdasarkan tiga aspek yang ditanya kepa da mahasiswa pada indikator "Kebiasaan dalam mengikuti perkuliahan Kalkulus" yaitu bisa le bih lama mengingat materi jika menggnakan software, lebih mudah memahami materi jika mengerjakan latihan menggunakan software MA PLE dan ingin berprestasi lebih baik dari sebe lumnya maka diketahui bahwa mahasiswa juru san matematika sangat termotivasi untuk berpres tasi lebih baik yaitu sekitar $88 \%$ dan mahasiswa menjawab selalu (SL) dan sekitar 35\% menja wab sering (SR). Sedangkan mahasiswa jurusan Kimia sekitar 92\% menjawab selalu (SL) untuk berprestasi lebih baik dan sekitar 50\% menja wab sering (SR). Hal ini berarti dalam menggu nakan bahan ajar berbasis ICT mahasiswa jurusn Matematika dan mahasiswa jurusan Kimia terma suk bersemangat dan berprestasi lebih baik,

\section{Hasil Belajar Mahasiswa}

Melalui tes hasil belajar yang maka dilihat rata-rata hasil belajar dari kedua kelompok ke mudian analisis tentang kemampuan pemecahan masalahnya. Hasil belajar mahasiswa jurusan matematika dan mahasiswa Kimia setelah peneli tian dapat dilihat pada tabel berikut.

Tabel Hasil Belajar

\begin{tabular}{|l|l|c|c|c|c|}
\hline $\begin{array}{l}\text { Mahasiswa } \\
\text { Jurusan }\end{array}$ & $\begin{array}{l}\text { Jml } \\
\text { Mhs. }\end{array}$ & $\bar{x}$ & SD & $X_{\text {maks }}$ & $X_{\text {min }}$ \\
\hline Matematika & 32 & 66,4 & 19,7 & 92 & 41 \\
\hline Kimia & 32 & 60,1 & 17,6 & 97 & 37 \\
\hline
\end{tabular}

Berdasarkan tabel di atas dapat dilihat bah wa rata-rata hasil belajar kalkulus mahasiswa ju rusan Matematika lebih baik dari hasil belajar mahasiswa Kimia namun rata-rata hasil belajar tersebut belum memuaskan. Dilihat rata-rata ha sil belajar maka rentang nilai mahasiswa masih berada di antara $\mathrm{C}$ dan $\mathrm{B}^{-}$yang berarti belum me muaskan. Sedangkan nilai yang tertinggi yang di peroleh mahasiswa jurusan matematika dan juru san Kimia sudah memuaskan (di atas 90) tetapi nilai paling rendah yang dicapai mahasiswa ma sih mengecewakan.

Selanjutnya, dari tes hasil belajar dianali sa kemampuan pemecahan masalah mahasiswa dalam menyelesaikan soal-soal aplikasi (soal ce rita) melalui lima langkah pemecahan masalah. Langkah pertama GIVEN yaitu memahami apa yang diketahui dan menuliskannya. Untuk lang kah pertama hampir semua mahasiswa sudah bisa menuliskan.

Langkah kedua ASKED yaitu memahami dan menuliskan yang ditanya dari masalah juga su dah hampir semua mahasiswa melakukannya.

Langkah ketiga RECALL yaitu mampu menen tukan teori teori yang sudah dipelajari untuk 
dipakai dalam penyelesaian masalah. Pada lang kah ini hanya sekitar $50 \%$ mahasiswa dapat menuliskan dengan benar teori yang diperlukan dan $20 \%$ tidak sempurna menuliskan teori yang diperlukan dan sekitar 30\% tidak mengetahui teori yang diperlukan.

Langkah ke-empat PLAN yaitu mahasiswa mulai mengaitkan teori dengan hal-hal yang diketahi dari masalah. Sebagian besar sudah bisa menga itkan antara teori yang mereka yang ketahui dengan hal yang diketahui.

Langkah ke-lima SOLVE yaitu mahasiswa mela kukan penyelesaian seperti mencari hasil turun an dan menentukan nilai-nilai yang menjadi nilai maksimum dan nilai minimum. Akibat dari tidak sempurnanya memahami dan mengingat teori yang diperlukan untuk menyelesaikan soal ditambah kurang teliti sehingga hanya sedikit (sekitar 40\%) mahasiswa dapat menyelesaikan soal dengan baik.

Langkah ke-enam CHECK yaitu memeriksa kembali hasil yang telah mereka peroleh. Langkah ini tidak begitu jelas dapat diperiksa karena jika pekerjaan mahasiswa dalam menyele saikan soal itu sudah benar, belum berarti mere ka tidak mencek tetapi bisa jadi itulah hasil pe meriksaan mereka kembali.

Berdasarkan data dan pengalaman selama perkuliahan menggunakan bahan ajar kalkulus berbasis ICT diketahui beberapa hal berikut.

i. Aktivitas mahasiswa dalam belajar mening kat karena mahasiswa dapat menggunakan ke majuan teknologi yang dipandu oleh bahan ajar berbasis ICT. Mahasiswa dapat melaku kan berbagai manipulasi beberapa soal dan membuat berbagai grafik dengan baik. Dari pengalaman tersebut mereka semakin asik dan menarik bekerja dengan MAPLE.

ii. Bekerja kooperatif bersama semakin efektif karena mereka langsung dapat melihat hasil yang dicari dan jika tidak bisa jalan dan hasil berbeda mereka bisa langsung bertanya de ngan temannya. Begitu juga saat diskusi ke las hamper semua bisa menyelesaikan tugastugas dengan baik walaupun tidak semua tu gas dapat dikerjakan di kampus karena untuk berlatih memerlukan waktu yang cukup ba nyak. Sehingga karena keterbatasan waktu be berapa soal dikerjakan diluar kampus.

iii. Penggunaan bahan ajar Kalkulus berbasis ICT telah menambah keterampilan dan penge tahuan mahasiswa dalam menerapkan kema juan teknologi untuk membantu pengetahuan Kalkulus mereka. Pada awal perkuliahan be lum semua mahasiswa terampil mengguna kan software MAPLE sehingga beberapa ma hasiswa menjadi lama menyelesaikan tugastugas namun terlihat semua mahasiswa tekun mengerjakan tugas-tugas tersebut.

Pada saat dosen menyajikan materi, maha siswa umumnya memperhatikan penjelasan do sen. Semua mahasiswa mendengarkan dengan baik perintah yang akan dikerjakan pada com puter untuk mengerjakan latihan. Sementara un tuk aktivitas mahasiswa mengajukan pertanyaan kepada dosen maupun kepada temannya saat diskusi sudah tidak banyak karena sebagian besar dari mahasiswa sudah bekerja sesuai pe rintah sehingga hasil yang diperoleh sudah be nar. Aktivitas menjawab pertanyaan dan mem beri komentar atas pertanyaan dosen sudah me nunjukkan hasil yang menggembirakan. Sudah banyak siswa yang melakukan aktivitas tersebut. Dengan demikian, aktivitas bertanya pada guru yang tergolong sedikit menunjukkan bahwa sis wa sudah banyak yang memahami materi yang sedang disajikan oleh dosen. Hal ini terlihat dari peningkatan jumlah mahasiswa yang melakukan kegiatan ini, banyaknya mahasiswa yang dapat menjawab pertanyaan dosen. Aktivitas tersebut juga dipengaruhi oleh materi yang diberikan pa da pertemuan tersebut.

Pada saat diskusi kelompok, umumnya mahasiswa sudah melakukan aktivitas berdisku si dengan temannya. Walaupun aktivitas terse but berfluktuatif tetapi sudah tergolong banyak. Sementara, untuk aktivitas siswa menggunakan buku sumber/modul, semua mahasiswa sudah melakukannya. Aktivitas menjelaskan kepada te man menjawab menunjukkan hasil yang meng gembirakan walaupun masih tergolong sedikit. Akan tetapi, masih terdapat mahasiswa yang be lum mau berdiskusi. Dengan demikian, umum nya mahasiswa telah mempelajari materi yang terdapat dalam bahan ajar Kalkulus berbasis ICT dengan berdiskusi, dan mereka telah mulai me mahami materi yang sedang dipelajari serta men jelaskannya kepada mahasiswa lain yang ada di kelompoknya.

Secara umum, aktivitas mahasiswa mening kat baik pada saat dosen menyajikan materi, pa da saat diskusi kelompok, dan pada saat diskusi kelas. Aktivitas tersebut juga dipengaruhi oleh materi yang sedang didiskusikan. Tanggapan ma hasiswa terhadap penggunaan bahan ajar berba sis ICT menurut mahasiswa jurusan Matematika dan jurusan Kimia adalah mereka setuju bahwa bahan ajar kalkulus berbasis ICT dapat mem 
bantu mereka menyelesaikan soal-soal Kalkulus. Mereka setuju bahwa bahan ajar berbasis ICT dapat membantu mereka dalam memahami ma teri dalam perkuliahan. Dengan demikian, bahan ajar Kalkulus berbasis ICT merupakan salah sa tu sumber belajar bagi mahasiswa yang dapat membantu mereka dalam pembelajaran, mengha dapi pembelajaran di kelas, dan membantu mere ka dalam memahami dan menyelesaikan soalsoal pekerjaan rumah (PR).

\section{KESIMPULAN}

Berdasarkan hasil penelitian dan pemba hasan diperoleh kesimpulan bahwa penggunaan bahan ajar Kalkulus berbasis ICT dapat 1) meng aktifkan mahasiswa dalam perkuliahan dan telah menambah keterampilan mahasiswa dalam me manfaatkan kemajuan teknologi informasi (IC T), 2) meningkatkan motivasi belajar, ketekunan mahasiswa dan semangat dalam perkuliahan $\mathrm{Kal}$ kulus, 3) meningkatkan hasil belajar mahasiswa pada beberapa materi seperti pemahaman ten tang bermacam-macam fungsi dan grafiknya, wa laupun belum untuk semua materi, 4) kemam puan pemecahan masalah mahasiswa cukup baik pada langkah 1 dan langkah 2 tetapi belum begi tu baik untuk langkah yang lain.

\section{DAFTAR PUSTAKA}

Bambang Priyo Darminto dan dan Wawan Setiawan, (2008), Studi Perbandingan Antara Model Pembelajaran Berbasis Komputer Da lam Peningkatan Kemampuan Berpikir Mate matis Tingkat Tinggi, Jurnal Issn:1979-9264 Teknologi Informasi Dan Komunikasi Volu me 1, Nomor 2, Desember 2008
Dimyati \&Mudjiono, (2002). Belajar dan Pem belajaran. Rineka Cipta : Bandung Pannen dan Purwanto; (1994); Penulisan Bahan Ajar Dalam Mengajar di Perguruan Tinggi (Prog ram Applied Approach); Jakarta; Pusat antar Universitas untuk Peningkatan dan Pengem bangan Aktivitas Instruksional; dirjen Dikti; Depdikbud

Helma H 2019 Penggunaan flow proof pada perkuliahan analisis real untuk meningkatkan kemampuan mahasiswa dalam menganalisis pembuktian Jurnal Eksakta Pendidikan (JEP), 3(1), 55-60. doi:10.24036/jep/vol3iss $1 / 326$

H Helma and D Murni 2020 Factors affecting students' capabilities in analyzing by using flow proof in real analysis lectures J. Phys.: Conf. Ser. 1554012040 https://iopscience. iop.org/article/10.1088/1742-6596/1554/1/ 012040

Hendra Kartika (2014), Pembelajaran Matemati ka Berbantuan Software MATLAB Sebagai Upaya Meningkatkan Kemampuan Komuni kasi Matematis dan Minat Belajar Siswa SMA, Judika Vol.2 N0.1, Jurnal Pendidikan UNSIKA

Moleong (2005), Metodologi Penelitian Kua litatif, Bandung, Remaja Rosdakarya.

Purcell, dkk (2001), Kalkulus. Edisi.9, Jakarta, Er langga

Saryanto, Teguh. (2005). "Media Pembelajaran Berbantuan Komputer" (Skripsi). FKI

Schunk and Barry Zimmerman. (2009). Moti vation and Self-Regulated Learning:Theory, Research, and Applications Journal of Higher Education Vol. 80, July-August, Hal 1-4.

Sukmadinata and Syaodih N 2006 Metode Penelitian Pendidikan (PT Remaja Rosdakar ya, Bandung) 